Srivastava, Rajendra. (2002) A Formal Framework of Auditor Independence Risk. Australian Accounting Review, 12, 31-38.

Publisher's Official Version: <http://onlinelibrary.wiley.com/journal/10.1111/\%28ISSN\%291835-2561>.

Open Access Version: <http://kuscholarworks.ku.edu/dspace/>.

[This document contains the author's accepted manuscript. For the publisher's version, see the link in the header of this document.]

\title{
A Formal Model of Auditor Independence Risk
}

\author{
By J.L. Turner, T.J. Mock, R.P. Srivastava \\ University of Memphis, University of Southern California and Maastricht University, \\ University of Kansas
}

\author{
Paper citation: \\ Srivastava, Rajendra. (2002) A Formal Framework of Auditor Independence Risk. Australian \\ Accounting Review, 12, 31-38.
}

Keywords:

Audit, Independence, Independence Risk

\begin{abstract}
:
Although the published literature on auditor independence is extensive, an accepted comprehensive theory, framework or model of auditor independence risk does not exist. This paper develops a formal model of auditor independence risk that may be used to begin a more rigorous investigation of auditor independence and various factors that are thought to affect this risk.

The sensitivity of the model to various influences on independence risk is assessed by developing a base-level model and then modifying the assumptions for that model. Three research questions are investigated: what is the impact on independence risk of a lack of auditor

integrity, the influence of professional standards, and the combined impact of opportunity and incentives.

Overall, analytical results show that integrity is the key variable in minimizing independence risk.

In addition, in cases where integrity could be questioned, independence risk is positively impacted by professional standards that are perceived to be effective and potentially negatively impacted by certain client characteristics and auditor incentives.
\end{abstract}


Australian Accounting Review, Issue 27, Vol. 12, No. 2, July 2002, pp. 31-38.

\title{
A Formal Model of Auditor Independence Risk
}

\author{
J. L. Turner \\ University of Memphis \\ T. J. Mock \\ University of Southern California and \\ Maastricht University
}

\author{
R. P. Srivastava \\ University of Kansas
}

Revised May 1, 2002

Prepared for resubmission to The Australian Accounting Review 


\title{
A Formal Model of Auditor Independence Risk
}

\author{
Abstract \\ Although the published literature on auditor independence is extensive, an accepted \\ comprehensive theory, framework or model of auditor independence risk does not exist. This \\ paper develops a formal model of auditor independence risk that may be used to begin a more \\ rigorous investigation of auditor independence and various factors that are thought to affect this \\ risk. \\ The sensitivity of the model to various influences on independence risk is assessed by \\ developing a base-level model and then modifying the assumptions for that model. Three \\ research questions are investigated: what is the impact on independence risk of a lack of auditor \\ integrity, the influence of professional standards, and the combined impact of opportunity and \\ incentives.
}

Overall, analytical results show that integrity is the key variable in minimizing independence risk. In addition, in cases where integrity could be questioned, independence risk is positively impacted by professional standards that are perceived to be effective and potentially negatively impacted by certain client characteristics and auditor incentives.

Key Words: Audit, Independence, Independence Risk 


\section{A Formal Model of Auditor Independence Risk}

\section{INTRODUCTION}

In November 2000, the Independence Standards Board (ISB) released an exposure draft titled "Statement of Independence Concepts - A Conceptual Framework for Auditor Independence" (ISB 2000). ${ }^{1}$ The exposure draft identifies four components of an independence framework: threats to auditor independence, safeguards to auditor independence, independence risk, and significance of threats and effectiveness of safeguards. In February 2001, the Securities and Exchange Commission (SEC) released a more detailed document, Final Rule: Revision of the Commission's Auditor Independence Requirements (SEC 2001). The final rules draw on the conceptual framework developed by the ISB and address specific situations in which an auditor is not independent of an audit client. Those situations include certain financial, employment, and business relationships and also transactions or situations involving the provision of non-audit services or involving the receipt of contingent fees.

In November 2001, a framework similar to that of the ISB exposure draft was included in the IFAC Code of Ethics for Professional Accountants (IFAC 2001). In the academic arena, Johnstone et al. (2001) developed a framework identifying factors that may increase auditor independence risk and factors that may mitigate that risk. Each of these frameworks and set of rules is general in nature and

1 The ISB was dissolved on July 31, 2001 without releasing a final version of its independence framework. Staff members released a report that was to have been presented to the full ISB, but a final form of the framework was never approved. 
Srivastava, Rajendra. (2002) A Formal Framework of Auditor Independence Risk. Australian Accounting Review, 12 , 31-38. Publisher's Official Version: <http://onlinelibrary.wiley.com/journal/10.1111/\%28ISSN\%291835-2561>.

Open Access Version: <http://kuscholarworks.ku.edu/dspace/>.

only suggests loose connections between various factors. None of the frameworks or set of rules attempt to formally relate these connections.

Independence risk (IR) is the risk that threats to auditor independence, to the extent that they are not mitigated by safeguards, compromise, or can reasonably be expected to compromise, an auditor's ability to make unbiased audit decisions (ISB 2000). In this paper, we develop a formal model of independence risk and use it to show how questions such as those involving complex interrelationships among model variables can be addressed. We recognize the various factors identified in the preliminary ISB framework, in the similar framework developed by the Ethics Committee of the International Federation of Accountants (IFAC 2001), and in the Johnstone et al. (2001) framework. While each framework notes that independence may be impaired without auditor intent, we focus on intentional impairment resulting from knowledgeable actions taken by the auditor.

Specifically, we demonstrate the usefulness of the model by examining three different research questions:

1. What is the impact of a lack of auditor integrity on auditor independence risk?

2. What is the impact of professional standards on auditor independence risk?

3. For an assumed level of lack of auditor integrity, what is the impact of opportunity and incentives on auditor independence risk?

\section{A FORMAL MODEL OF INDEPENDENCE RISK}

Independence risk can be viewed as a function of three factors: incentive, opportunity, and auditor integrity and can be represented as: 
Srivastava, Rajendra. (2002) A Formal Framework of Auditor Independence Risk. Australian Accounting Review, 12, 31-38.

Publisher's Official Version: <http://onlinelibrary.wiley.com/journal/10.1111/\%28ISSN\%291835-2561>.

Open Access Version: <http://kuscholarworks.ku.edu/dspace/>.

$$
\mathrm{IR}=f(\mathrm{IN}, \mathrm{OP}, \mathrm{AI})
$$

where IR represents Independence Risk, IN represents a continuum of the various types of incentives that may entice auditors to violate ethics guidelines, OP represents a continuum of the opportunities available to the auditor to bias professional judgments, and AI represents a continuum measuring the lack of auditor's ethical moral integrity. For IR to exist, each component is necessary, but not sufficient. That is, independence will be impaired only when the auditor lacks integrity and when there is both opportunity and incentive.

For an auditor to knowingly allow his or her decisions to become biased, some form of incentive must exist. Otherwise, the auditor would be risking sanctions ranging from censure to expulsion from the profession with no compensating benefit. The various codes of ethics (e.g. IFAC 2001) and regulatory rules (e.g. SEC 2001) identify numerous incentives such as financial and employment relationships and non-audit services that may impact independence. Johnstone et al. (2001) categorize these as direct incentives and indirect incentives. Examples of direct incentives include financial investment in the client, consulting fees, contingent fees, promises of future employment, and material financial dependence.

Indirect incentives include situations such as when the auditor has strong interpersonal relationships with client personnel, or when family members have a relationship with the client through financial investments or employment. A substantial portion of each professional code of ethics focuses on controlling direct and indirect incentives, but controls also exist in audit firm and regulatory agency guidelines.

A second factor necessary for IR to exist is an opportunity for bias by the auditor to have a significant impact on the auditor's report. Opportunity may exist in the presence of complex financial transactions 
Srivastava, Rajendra. (2002) A Formal Framework of Auditor Independence Risk. Australian Accounting Review, 12, 31-38.

Publisher's Official Version: <http://onlinelibrary.wiley.com/journal/10.1111/\%28ISSN\%291835-2561>

Open Access Version: <http://kuscholarworks.ku.edu/dspace/>.

or when management must make significant estimates or assumptions. Opportunity for auditor bias also may exist when difficult interpretations of generally accepted accounting principles must be made and applied or in determining an appropriate level of reporting materiality. Opportunities for bias generally are controlled by generally accepted auditing standards, by audit firm policies, by regulatory agencies, and through effective corporate governance. The U.S. Securities and Exchange Commission (SEC) Staff Accounting Bulletin 99 (SEC 1999), for example, focuses on materiality and suggests that auditors may impair independence by allowing clients to influence materiality decisions.

Auditor integrity, and the opposite condition, lack of integrity, relates to the propensity of an individual auditor to engage in inappropriate activities. An auditor with high ethical standards may remain completely independent in thought and action despite the existence of strong incentives and available opportunities. Other auditors, however, may find incentives at some point to be too enticing to resist and, given opportunities, may allow financial statement to be published without issuing an appropriate opinion. Auditor integrity is controlled to the extent possible by audit firm culture (Ponemon 1992), procedures and training, and by restrictions on entry into the profession.

To deal with the calculus through which we combine information to assess independence risk, there are several frameworks and formal languages that might be used. Included are those based on probability theory, fuzzy logic, possibility theory (Zadeh 1978, 1979) or belief functions (Shafer 1976, Smets 1990a, 1990b, 1998). These frameworks have different tradeoffs and seem to be more applicable in certain problem domains than in other domains. 
Srivastava, Rajendra. (2002) A Formal Framework of Auditor Independence Risk. Australian Accounting Review, 12, 31-38. Publisher's Official Version: <http://onlinelibrary.wiley.com/journal/10.1111/\%28ISSN\%291835-2561>.

Open Access Version: <http://kuscholarworks.ku.edu/dspace/>.

Srivastava and Shafer (1992) argue that belief functions provide a more flexible and adaptable way to combine evidence (see also, Akresh et al. 1988). One aspect of this flexibility is that the belief function framework reduces to the Bayesian framework in some situations. Belief functions also provide a coherent way of mapping uncertainty judgments in auditing (Harrison 1999, Harrison et al. 2002), and incorporating ambiguity within decision-making (Srivastava 1997, Srivastava and Mock 2000).

In the evidential network approach under belief functions, items of evidence are combined using Dempster's rule of combination. We have used the computer program "Auditor's Assistant" (Shafer et al.1988) to draw the evidential network and to perform our analyses using the belief-function framework.

Figure 1 represents our basic model of auditor independence risk and is intended to represent an analysis viewed from the standpoint of an external observer, such as an investor. The model has two types of nodes—variables and independence factors.

The focus of the model is the variable node 'Maintain Independence' that represents the level of confidence that the auditor maintains independence throughout the audit. The Maintain Independence variable has two components - the first representing belief that independence is maintained and the second representing belief that independence in not maintained. These two values do not necessarily add to one because of residual uncertainty resulting from a lack of knowledge on the part of the observer. ${ }^{2}$ One minus the level of belief that independence is maintained is Independence Risk.

${ }^{2}$ For a review of belief functions and an explanation of residual uncertainty, see Srivastava and Mock (2002). 
Srivastava, Rajendra. (2002) A Formal Framework of Auditor Independence Risk. Australian Accounting Review, 12, 31-38.

Publisher's Official Version: <http://onlinelibrary.wiley.com/journal/10.1111/\%28ISSN\%291835-2561>.

Open Access Version: <http://kuscholarworks.ku.edu/dspace/>.

The independence factors are those factors that are thought to influence IR as identified in the professional literature. The numerical values shown in the independence factor nodes (the rectangles) in the model represent assessments made by the external observer and serve as input into the model variables, represented by rectangles with rounded corners. The assessments in the rectangles are determined by an observer assessing IR and each assessment has two values, shown in parentheses, for each linked variable related to the particular independence factor. The first value shown represents as assessment of the strength of evidence supporting the variable (for) and the second value represents the strength of evidence negating the variable (against).

For example, the Auditor's Ethical and Moral Characteristics assessment in Figure 1 is related to the Integrity variable. The first number in the set of parentheses indicates the observer's belief that the auditor has integrity, in this case assumed to be 0.90 on a scale of zero to one. A zero value would indicate the assessor has no evidence while a value of one represents certainty. More specifically, a zero level of support in favor of Integrity means that there is no evidence that the auditor has integrity and a value of one means that the assessor is certain that the auditor has complete integrity. In Figure 1, the second number in this set of parentheses, zero, indicates that in the judgment of the observer there is no evidence indicating a lack of integrity

The variable Maintain Independence is related with three other variables: 'Integrity', 'No Incentive', and 'No Opportunity' through an 'OR' relationship. This relationship is represented by the hexagonal box containing 'OR' in Figure 1. The 'OR' implies that independence risk will be minimal in any one of the following conditions: the auditor has high integrity, or the auditor has no incentive to benefit, or there is 
Srivastava, Rajendra. (2002) A Formal Framework of Auditor Independence Risk. Australian Accounting Review, 12 , 31-38.

Publisher's Official Version: <http://onlinelibrary.wiley.com/journal/10.1111/\%28ISSN\%291835-2561>.

Open Access Version: <http://kuscholarworks.ku.edu/dspace/>.

no opportunity to benefit. Conversely, there will be a lack of independence only when there is a lack of integrity and there is incentive and opportunity.

These three variables represented in Figure 1 by rectangular boxes with rounded corners are connected to rectangular boxes representing independence factors pertaining to the variables as described above. For example, 'Firm Policy' represents a factor that pertains to the variables 'Integrity', 'No Incentive', and 'No Opportunity'. Audit firm policies encourage high integrity, help mitigate auditors' incentives, and limit opportunities to benefit inappropriately from the audit.

\section{Similarly, 'Professional Policies', 'External Regulatory Agencies’ and 'Corporate Governance’ are} three other factors that pertain to the same three variables. These factors also encourage auditor's integrity and mitigate auditors' incentive and opportunity to benefit from the audit. The factor 'Auditor Characteristics' in the model only pertains directly to the variable 'Integrity'. The factor 'Direct and Indirect' indicate direct and indirect incentives as discussed above.

When assessing independence risk, it is important to obtain information on audit firm policies in these areas and to assess the effects of various other influences on IR. This model can assist in the assessment process as is demonstrated in the following analysis and results section. Figure 1, of course, is only one way to specify how the factors that influence independence risk may be interrelated. 
Srivastava, Rajendra. (2002) A Formal Framework of Auditor Independence Risk. Australian Accounting Review, 12 , 31-38.

Publisher's Official Version: <http://onlinelibrary.wiley.com/journal/10.1111/\%28ISSN\%291835-2561>.

Open Access Version: <http://kuscholarworks.ku.edu/dspace/>.

\section{ANALYSIS AND RESULTS}

The sensitivity of the model to various influences on IR is assessed by developing a base-level model and then modifying the assumptions for that model to examine three research questions. The first question examines the impact of a lack of auditor integrity on IR. The second research question investigates the influence of professional standards, such as codes of ethics, on IR. The third research question investigates for an assumed level of belief regarding lack of integrity, the impact of opportunity and incentives on IR.

\section{Base-Level Model}

To analyze the model shown in Figure 1, the observer first assigns values related to each factor in the rectangular boxes pertaining to each linked variable and then calculates the influence of such values on IR. In other words, given the information available, the observer needs to assess the level of support in favor of the variable or its negation. The assumed values for the various variables in the base-level model are detailed in Table 1.

\section{----- Table 1 here -----}

While belief values are subjective, those in Table 1 are selected to represent realistic circumstances in actual audits. In our base-level model, assuming the assessor has supportive information on the Auditor's Ethical and Moral Characteristics, we assign belief values of 0.90 supporting (for) auditor integrity and zero belief value negating (against) auditor integrity. These levels indicate that the auditor being assessed appears to the observer to have high ethical and moral standards and that there is no 
Srivastava, Rajendra. (2002) A Formal Framework of Auditor Independence Risk. Australian Accounting Review, 12, 31-38. Publisher's Official Version: <http://onlinelibrary.wiley.com/journal/10.1111/\%28ISSN\%291835-2561>.

Open Access Version: <http://kuscholarworks.ku.edu/dspace/>.

evidence indicating otherwise. Such assumptions appear to be reasonable based on the numerous screening procedures employed by the profession and by individual auditing firms.

As noted previously, for Independence Risk to exist, there must be some form of opportunity allowing the auditor to make biased audit decisions. Part of the opportunity exists with the audit client itself, where a volatile business environment, transactions for which GAAP is not well defined, and the complexity of transactions each offer the opportunity for bias. Opportunity also is present when management must make difficult estimates and assumptions or when judgments required of the auditor relate to client or auditee characteristics, such as establishing reporting materiality levels. In Table 1 we assume a constant against belief value of 0.70 from Auditee Characteristics. Since the variable being assessed is 'No Opportunity', a 0.70 against belief value indicates that the audit situation offers a number of opportunities for the auditor to develop biased judgments.

Firm Policies are assigned a for belief value of 0.40 for the base-level model. This moderate value is assumed because under professional guidelines, each individual audit firm has the responsibility of ensuring independence on each audit engagement. This is noted specifically in the IFAC Code of Ethics for Professional Accountants (IFAC 2001) “...firms and members of assurance teams have an obligation to identify and evaluate circumstances and relationships that create threats to independence and to take appropriate action to eliminate these threats or to reduce them to an acceptable level by the application of safeguards." Firm policies impact Auditor Integrity through hiring policies, internal codes of ethics, and training. Incentives are impacted through restrictions and monitoring of financial and familial relationships and similar activities. Opportunities are controlled through client screening, 
Srivastava, Rajendra. (2002) A Formal Framework of Auditor Independence Risk. Australian Accounting Review, 12, 31-38.

Publisher's Official Version: <http://onlinelibrary.wiley.com/journal/10.1111/\%28ISSN\%291835-2561>.

Open Access Version: <http://kuscholarworks.ku.edu/dspace/>.

supervision, review policies, and audit firm guidance in regards to such factors as audit program design and materiality choice.

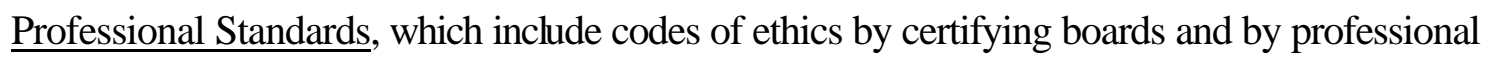
organizations, peer review activities, and required continuing education, impact all three components of IR. For the influence of Professional Standards, in the base-level model we assume a constant for belief value of 0.20 for the influence on Integrity, indicating influence primarily through restrictions regarding certifications, by establishing codes of ethics, and by having the ability to sanction auditors who violate standards. A for belief value of 0.40 is assumed for the influence on No Incentive, reflecting specific guidance regarding inappropriate direct and indirect incentives. A for belief value of 0.30 for the influence on No Opportunity is assumed, reflecting a moderate level of influence on audits through activities such as establishing generally accepted auditing standards and providing guidance on issues such as materiality choice.

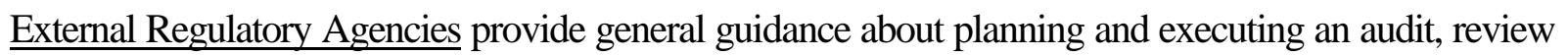
completed audits and investigate audit failures. The influence of External Regulatory Agencies is recognized at belief values similar to those for Professional Policies. For the base model we assume for belief values of 0.20 for influence on Integrity, 0.40 for influence on No Incentives, and 0.30 for influence on No Opportunity.

Corporate Governance provides the structure through which the objectives of a company are set, and the means of attaining those objectives and monitoring performance (OECD 1999). Good corporate governance should provide proper incentives for the board and management to pursue objectives that 
Srivastava, Rajendra. (2002) A Formal Framework of Auditor Independence Risk. Australian Accounting Review, 12, 31-38.

Publisher's Official Version: <http://onlinelibrary.wiley.com/journal/10.1111/\%28ISSN\%291835-2561>.

Open Access Version: <http://kuscholarworks.ku.edu/dspace/>.

are in the interests of the company and shareholders and should facilitate effective monitoring. Ramsay (2001) included a number of recommendations related to improving corporate governance, including (1) mandating the existence of qualified audit committees on boards of directors, (2) specifying the composition of audit committees, and (3) specifying the duties and of zero is responsibilities of the audit committee. Some, but not all, recommendations made by Ramsay were adopted in the IFAC Code of Ethics for Professional Accountants released in November 2001 (Hayes 2002; IFAC 2001). For the base-level model we assume a for belief value of 0.40 as input for each of the Integrity, No Incentive, and No Opportunity variables. It also is assumed that there is no evidence against the variables influenced by Corporate Governance and thus a value assigned.

Direct and Indirect Incentives are assigned an against belief value of 0.90 . This value assumes that the influence of direct and indirect incentives, which might include various forms of personal gain, can be quite substantial.

Given these belief values, a determination of the overall belief that the audit does Maintain Independence can be calculated. As noted earlier, we use a Belief Function calculus to estimate these values.

Assuming the base-level values of Table 1, it can be seen in Figure 1 that the Integrity variable has a value of 0.915 for and a value of zero against. The increase of 0.015 from the value of 0.90 obtained from Auditor's Ethical and Moral Characteristics results from additional comfort derived from other inputs, such as Firm Policy. 
Srivastava, Rajendra. (2002) A Formal Framework of Auditor Independence Risk. Australian Accounting Review, 12, 31-38.

Publisher's Official Version: <http://onlinelibrary.wiley.com/journal/10.1111/\%28ISSN\%291835-2561>.

Open Access Version: <http://kuscholarworks.ku.edu/dspace/>.

The No Incentive variable has a for value of 0.185 and an against value of 0.734 . This indicates that the high against belief value of 0.90 for Direct and Indirect Incentives not only has been reduced by factors such as Firm Policy, but that the mitigating variables now provide a 0.185 for belief value.

Similarly, the No Opportunity variable has a for value of 0.155 and an against value of 0.591 . The variable also has been influenced by the mitigating factors of Firm Policies, Professional Standards, External Regulatory Agencies, and Corporate Governance.

Finally, the Maintain Independence variable combines the Integrity, No Incentive, and No Opportunity variable to a for value of 0.918 , indicating a relatively high belief that auditor independence is maintained. The zero against value indicates that there is no unmitigated evidence that independence is impaired. One minus the for value results in Independence Risk of 0.082. As there is no unmitigated against evidence that independence is impaired, IR consists solely of the residual uncertainty resulting from lack of evidence.

Given these results for the base-level model, we now can examine the sensitivity of the model to changes in different factors affecting Integrity, No Incentive, and No Opportunity. We begin this with Research Question 1.

Research Question 1: What is the impact of lack of integrity on auditor independence risk?

Hiring and certification processes, codes of ethics, and peer influences all serve to increase the likelihood that auditors exhibit high moral and ethical characteristics. Audit firms tend to hire top graduates, usually after consultation with faculty members and others regarding the graduates' academic abilities and character. The certification process serves as an additional filter by excluding individuals 
Srivastava, Rajendra. (2002) A Formal Framework of Auditor Independence Risk. Australian Accounting Review, 12, 31-38. Publisher's Official Version: <http://onlinelibrary.wiley.com/journal/10.1111/\%28ISSN\%291835-2561>.

Open Access Version: <http://kuscholarworks.ku.edu/dspace/>.

with criminal records and by requiring knowledge of the code of ethics. Even after certification, individuals can be expelled from the profession by being convicted of crimes or because of other transgressions.

To examine the influence of the moral and ethical propensities of the auditor on IR, as shown in Figure 2, we examine the Auditor Ethical and Moral Characteristics for belief variable at three distinct levels: zero, indicating no knowledge about integrity, 0.45 indicating a moderate level of integrity, and 0.90 indicating a high level of integrity. With the for belief value at zero, we increment the against belief value in steps of 0.10 from a value of zero to a value of 1.00 . With the for belief value at 0.45 , the against belief value is incremented in steps of 0.10 from zero to 0.50 and with the for belief value at 0.90, the against belief value is examined at zero and 0.1. Other for and against belief values in Table 1, columns 5 and 6 , are the same values as in the base-level model.

----- Figure 2 here -----

As can be seen in Figure 2, as the for belief value from Auditor's Ethical and Moral Characteristics increases from zero to 0.90 , IR decreases from about 0.18 to 0.04 . However, for a given level of a for belief value, as the against belief value, i.e. lack of integrity, increases, the IR increases, but at a much smaller rate. This finding indicates that unless the observer has a relatively high confidence in the auditor, IR likely will be at a very high and likely unacceptable level.

Research Question 2: What is the impact of professional standards on auditor independence risk? 
Srivastava, Rajendra. (2002) A Formal Framework of Auditor Independence Risk. Australian Accounting Review, 12 , 31-38.

Publisher's Official Version: <http://onlinelibrary.wiley.com/journal/10.1111/\%28ISSN\%291835-2561>.

Open Access Version: <http://kuscholarworks.ku.edu/dspace/>.

One mitigating factor depended on by users of financial statements is participation by various regulatory agencies in setting standards related to independence. Such agencies may be involved in the setting of standards related to audits, in the enforcement of those standards, or both (e.g. Pincus et al. 1987).

To examine the influence of regulatory agencies on IR, we vary the for belief values as follows (See Figure 3 and Table 1, columns 7 and 8). For the influence of Professional Standards on Integrity, we vary the for belief values from 0.10 to 0.60 ; for No Incentive, we vary the for belief value Professional Standards from 0.30 to 1.00; and for No Opportunity, the for belief values are varied from 0.20 to 0.90. For each combination, Independence Risk is calculated for two for belief values of Auditor Ethical and Moral Characteristics- 0.80 and 0.90 .

----- Figure 3 here -----

It can be seen from Figure 3 that Professional Standards do have an observable effect on IR in that IR decreases substantially as the influence of professional standards is assessed to be stronger. In addition, when compared to Figure 2, it can be seen that even when Auditor Ethical and Moral Characteristics are assumed to be 0.90 , Professional Standards still are able to reduce IR to much lower levels.

Research Question 3: For an assumed level of lack of integrity, what is the impact of opportunity and incentive on auditor independence risk?

It is of interest to examine how different levels of incentives and how different levels of opportunity affect IR. To accomplish this, we increment beliefs from two variables. First, the belief from Direct and Indirect Incentives is varied as this belief value impacts only the No Incentives variable (See Table 1, 
Srivastava, Rajendra. (2002) A Formal Framework of Auditor Independence Risk. Australian Accounting Review, 12 , 31-38.

Publisher's Official Version: <http://onlinelibrary.wiley.com/journal/10.1111/\%28ISSN\%291835-2561>.

Open Access Version: <http://kuscholarworks.ku.edu/dspace/>.

columns 9 and 10). Second, the belief from Auditee Characteristics is varied as this belief value impacts only the No Opportunity variable.

----- Figure 4 here -----

As can be seen in Figure 4, as the belief for Incentives from Direct and Indirect Incentives is

incremented in steps of 0.10 from zero to 1.00 , IR essentially doubles from 0.11 to 0.20 . This indicates that control of incentives is an important part of maintaining auditor independence. It also is seen that as the against belief for No Opportunities from Auditee Characteristics is incremented from zero to 1.00, IR increases from 0.13 to 0.19 .

\section{SUMMARY}

The main purpose of this paper is to develop and then evaluate a formal model of auditor independence risk. This model has been developed as an initial step in understanding the importance of various factors identified in the literature which are thought to affect independence. The model is used to address three research questions involving assessing the impact of four factors on Independence Risk:

1. auditor integrity,

2. professional standards

3. direct and indirect incentives and

4. auditee characteristics.

Initial analyses show that independence risk is sensitive to each of these factors although the magnitude of the effects varies substantially across the cases examined. More specifically, the main results show that integrity is the key variable in minimizing independence risk. In addition, in cases where integrity 
Srivastava, Rajendra. (2002) A Formal Framework of Auditor Independence Risk. Australian Accounting Review, 12, 31-38.

Publisher's Official Version: <http://onlinelibrary.wiley.com/journal/10.1111/\%28ISSN\%291835-2561>.

Open Access Version: <http://kuscholarworks.ku.edu/dspace/>.

could be questioned, independence risk is reduced when there are professional standards that are perceived to be effective and can be increased by certain client characteristics and auditor incentives.

Given that this paper is a first attempt at developing a formal model of independence risk, the model presented is quite simplified. In fact, the modeling results could be interpreted as merely establishing the face validity of the model as well as supporting common beliefs about the importance of controlling incentives and opportunities. Thus, future analytical research is needed to develop more complex models. Such models may include additional influences, such as environmental complexity, that may affect independence risk and also can involve more complex interrelationships among variables. For example, a model may introduce a relationship between incentive and integrity where incentive influences integrity, i.e. a very strong incentive may influence the auditor to compromise his or her integrity. Similarly, a great opportunity may entice the auditor to compromise his or her integrity.

Empirical research also is needed to examine the effects of various influences and to validate analytical findings in a field setting. Once the model has been empirically validated and appropriate metrics have been established, the model can be useful in measuring the relationship between auditor integrity and independence risk. Similarly, an empirically grounded model can examine the influence of professional standards on reducing incentives and the corresponding impact on independence risk. Such studies not only can validate the analytical findings shown in this paper, but also can improve audit practice by allowing incorporation of the features of the model into actual audits to help control independence risk. 
Srivastava, Rajendra. (2002) A Formal Framework of Auditor Independence Risk. Australian Accounting Review, 12 , 31-38.

Publisher's Official Version: <http://onlinelibrary.wiley.com/journal/10.1111/\%28ISSN\%291835-2561>.

Open Access Version: <http://kuscholarworks.ku.edu/dspace/>. 
Srivastava, Rajendra. (2002) A Formal Framework of Auditor Independence Risk. Australian Accounting Review, 12, 31-38.

Publisher's Official Version: <http://onlinelibrary.wiley.com/journal/10.1111/\%28ISSN\%291835-2561>.

Open Access Version: <http://kuscholarworks.ku.edu/dspace/>.

\section{REFERENCES}

Akresh, A.D., J.K. Loebbecke, and W.R. Scott. 1988. Audit approaches and techniques. In Research Opportunities in Auditing: The Second Decade, edited by A. R. Abdel-khalik and Ira Solomon. Sarasota, FL: AAA, pp. 13-55.

Ethics Committee of the International Federation of Accountants (IFAC). 2001. IFAC Code of Ethics for Professional Accountants. New York.

Harrison, K. 1999. Evaluation and Aggregation of Audit Evidence under Uncertainty: An Empirical Study of Belief Functions. Ph.D. Dissertation, School of Business, University of Kansas.

Harrison, K., R. P. Srivastava, and R. D. Plumlee. 2002. Auditors' Evaluations of Uncertain Audit Evidence: Belief Functions versus Probabilities. In Belief Functions in Business Decisions, edited by R. P. Srivastava and T. Mock, Physica-Verlag, Heidelberg, Springer-Verlag Company

Hayes, Colleen. 2002. The Ramsay Report (2001) and the regulation of audit independence in Australia. Working paper. Edith Cowan University.Independence Standards Board (ISB). 2000. A conceptual framework for auditor independence. Discussion Memorandum, DM 00-1 (February).

Johnstone K. M., M. H. Sutton and T. D. Warfield. 2001. Antecedents and Consequences of Independence Risk: Framework for Analysis. Accounting Horizons (Forthcoming, March 2001, $15(1)$.

Organization for Economic Co-operation and Development (OECD). 1999. OECD Principles of Corporate Governance. Directorate for Financial, Fiscal and Enterprise Affairs, Ad Hoc Task Force on Corporate Governance.

Pincus, K. V., W.W. Holder and T. J. Mock. 1987. Reducing the incidence of fraudulent financial reporting: The role of the Securities and Exchange Commission. Research Report \# 3, SEC and Financial Reporting Institute. University of Southern California.

Ponemon, L.A. 1992. Ethical reasoning and selection-socialization in accounting. Accounting, Organizations \& Society 17 (3/4): 239-258.

Ramsay, I. 2001. Independence of Australian Company Auditors. Commonwealth of Australia.

Securities and Exchange Commission (SEC). 1999. SEC Staff Accounting Bulletin: No. 99 Materiality. (August 12). 
Srivastava, Rajendra. (2002) A Formal Framework of Auditor Independence Risk. Australian Accounting Review, 12, 31-38.

Publisher's Official Version: <http://onlinelibrary.wiley.com/journal/10.1111/\%28ISSN\%291835-2561>.

Open Access Version: <http://kuscholarworks.ku.edu/dspace/>.

Securities and Exchange Commission (SEC). 2001. Final Rule: Revision of the Commission's Auditor Independence Requirements (17 CFR Parts 210 and 240).

Shafer, G. 1976. A Mathematical Theory of Evidence. Princeton University Press.

Shafer, G., P.P. Shenoy, and R. P. Srivastava. 1988. Auditor's Assistant: A knowledge engineering tool for audit decisions. Proceedings of the 1988 Touche Ross/University of Kansas Symposium on Auditing Problems. Lawrence, KS: School of Business, University of Kansas, pp. 6184.

Smets, P. 1990a. The Combination of Evidence in the Transferable Belief Model. IEEE Transactions on Pattern Analysis and Machine Intelligence, 12, 5 (May).

Smets, P. 1990b. Constructing the Pignistic Probability Function in a Context of Uncertainty.

Uncertainty in Artificial Intelligence 5. ed. by Henrion, M., Shachter, R.D., Kanal, L.N., and Lemmer, J.F. North-Holland: Elsevier Science Publishers B.V.

Smets, P. 1998. The Transferable Belief Model For Quantified Belief Representation. Quantified Representation for Uncertainty and Imprecision, Vol. 1. Edited by P. Smets. Kluwer Academic Publishers

Srivastava, R. P. 1997. Decision Making Under Ambiguity: A Belief-Function Perspective. Archives of Control Sciences, Vol. 6 (XLII): 5-27.

Srivastava, R. P., and T. Mock. 2000. Belief functions in accounting behavioral research, Advances in Accounting Behavioral Research. Vol. 3: 225-242.

Srivastava, R. P. and G. Shafer. 1992. Belief-Function Formulas for Audit Risk. The Accounting Review, Vol. 67, No. 2 (April): 249-283.

Zadeh, L. A. 1978. Fuzzy sets as a Basis for a Theory of Probability. Fuzzy Sets and Systems, 1: 328.

Zadeh, L. A. 1979. A Theory of Approximate Reasoning. Machine Intelligence, edited by J. E. Ayes, D. Mitchie andn L. I. Mikulich. Chichester, UK: Ellis Horwood. 
Srivastava, Rajendra. (2002) A Formal Framework of Auditor Independence Risk. Australian Accounting Review, 12, 31-38.

Publisher's Official Version: <http://onlinelibrary.wiley.com/journal/10.1111/\%28ISSN\%291835-2561>.

Open Access Version: <http://kuscholarworks.ku.edu/dspace/>.

Table 1

Assumed Variable Values

\begin{tabular}{|c|c|c|c|c|c|c|c|c|c|}
\hline \multirow[b]{3}{*}{ Variable } & \multirow[b]{3}{*}{ Linked Variable } & \multicolumn{8}{|c|}{ Strength of Belief About Evidence } \\
\hline & & \multicolumn{2}{|c|}{$\begin{array}{c}\text { Baseline Case } \\
\text { (Figure 1) }\end{array}$} & \multicolumn{2}{|c|}{ Research Question 1} & \multicolumn{2}{|c|}{ Research Question 2} & \multicolumn{2}{|c|}{ Research Question 3} \\
\hline & & For $^{1}$ & Against $^{2}$ & For & Against & For & Against & For & Against \\
\hline $\begin{array}{l}\text { Auditor } \\
\text { Characteristics }\end{array}$ & Integrity & 0.90 & 0.00 & $0.00-1.00$ & $1.00-0.00$ & .90 & 0.00 & 0.80 & 0.20 \\
\hline $\begin{array}{l}\text { Auditee } \\
\text { Characteristics }\end{array}$ & No Opportunity & 0.00 & 0.70 & 0.00 & 0.70 & 0.00 & 0.70 & 0.00 & $\begin{array}{c}0.70 \\
0.00-1.00 \\
\end{array}$ \\
\hline Firm Policies & $\begin{array}{l}\text { Integrity } \\
\text { No Incentive } \\
\text { No Opportunity }\end{array}$ & $\begin{array}{l}0.40 \\
0.40 \\
0.40\end{array}$ & $\begin{array}{l}0.00 \\
0.00 \\
0.00\end{array}$ & $\begin{array}{l}0.40 \\
0.40 \\
0.40\end{array}$ & $\begin{array}{l}0.00 \\
0.00 \\
0.00\end{array}$ & $\begin{array}{l}0.40 \\
0.40 \\
0.40\end{array}$ & $\begin{array}{l}0.00 \\
0.00 \\
0.00\end{array}$ & $\begin{array}{l}0.40 \\
0.40 \\
0.40\end{array}$ & $\begin{array}{l}0.00 \\
0.00 \\
0.00\end{array}$ \\
\hline $\begin{array}{l}\text { Professional } \\
\text { Standards }\end{array}$ & $\begin{array}{l}\text { Integrity } \\
\text { No Incentive } \\
\text { No Opportunity }\end{array}$ & $\begin{array}{l}0.20 \\
0.40 \\
0.30 \\
\end{array}$ & $\begin{array}{l}0.00 \\
0.00 \\
0.00 \\
\end{array}$ & $\begin{array}{l}0.20 \\
0.40 \\
0.30 \\
\end{array}$ & $\begin{array}{l}0.00 \\
0.00 \\
0.00 \\
\end{array}$ & $\begin{array}{l}0.10-0.60 \\
0.30-1.00 \\
0.15-0.90 \\
\end{array}$ & $\begin{array}{l}0.00 \\
0.00 \\
0.00 \\
\end{array}$ & $\begin{array}{l}0.20 \\
0.40 \\
0.30 \\
\end{array}$ & $\begin{array}{l}0.00 \\
0.00 \\
0.00 \\
\end{array}$ \\
\hline $\begin{array}{l}\text { External Regulatory } \\
\text { Agencies }\end{array}$ & $\begin{array}{l}\text { Integrity } \\
\text { No Incentive } \\
\text { No Opportunity }\end{array}$ & $\begin{array}{l}0.20 \\
0.40 \\
0.30 \\
\end{array}$ & $\begin{array}{l}0.00 \\
0.00 \\
0.00 \\
\end{array}$ & $\begin{array}{l}0.20 \\
0.40 \\
0.30 \\
\end{array}$ & $\begin{array}{l}0.00 \\
0.00 \\
0.00 \\
\end{array}$ & $\begin{array}{l}0.20 \\
0.40 \\
0.30 \\
\end{array}$ & $\begin{array}{l}0.00 \\
0.00 \\
0.00 \\
\end{array}$ & $\begin{array}{l}0.20 \\
0.40 \\
0.30 \\
\end{array}$ & $\begin{array}{l}0.00 \\
0.00 \\
0.00 \\
\end{array}$ \\
\hline $\begin{array}{l}\text { Corporate } \\
\text { Governance }\end{array}$ & $\begin{array}{l}\text { Integrity } \\
\text { No Incentive } \\
\text { No Opportunity }\end{array}$ & $\begin{array}{l}0.40 \\
0.40 \\
0.40 \\
\end{array}$ & $\begin{array}{l}0.00 \\
0.00 \\
0.00 \\
\end{array}$ & $\begin{array}{l}0.40 \\
0.40 \\
0.40 \\
\end{array}$ & $\begin{array}{l}0.00 \\
0.00 \\
0.00 \\
\end{array}$ & $\begin{array}{l}0.40 \\
0.40 \\
0.40 \\
\end{array}$ & $\begin{array}{l}0.00 \\
0.00 \\
0.00 \\
\end{array}$ & $\begin{array}{l}0.40 \\
0.40 \\
0.40 \\
\end{array}$ & $\begin{array}{l}0.00 \\
0.00 \\
0.00 \\
\end{array}$ \\
\hline $\begin{array}{l}\text { Direct and Indirect } \\
\text { Incentives }\end{array}$ & No Incentive & 0.00 & 0.90 & 0.00 & 0.90 & 0.00 & 0.90 & 0.00 & $\begin{array}{c}0.00-1.00 \\
0.90\end{array}$ \\
\hline
\end{tabular}

${ }^{1}$ For values support the Linked Variable

${ }^{2}$ Against values negate the Linked Variable 
Srivastava, Rajendra. (2002) A Formal Framework of Auditor Independence Risk. Australian Accounting Review, 12, 31-38. Publisher's Official Version: <http://onlinelibrary.wiley.com/journal/10.1111/\%28ISSN\%291835-2561>.

Open Access Version: <http://kuscholarworks.ku.edu/dspace/>.

\section{Figure 1}

Model* of Auditor Independence Risk with Base-Level Belief Values

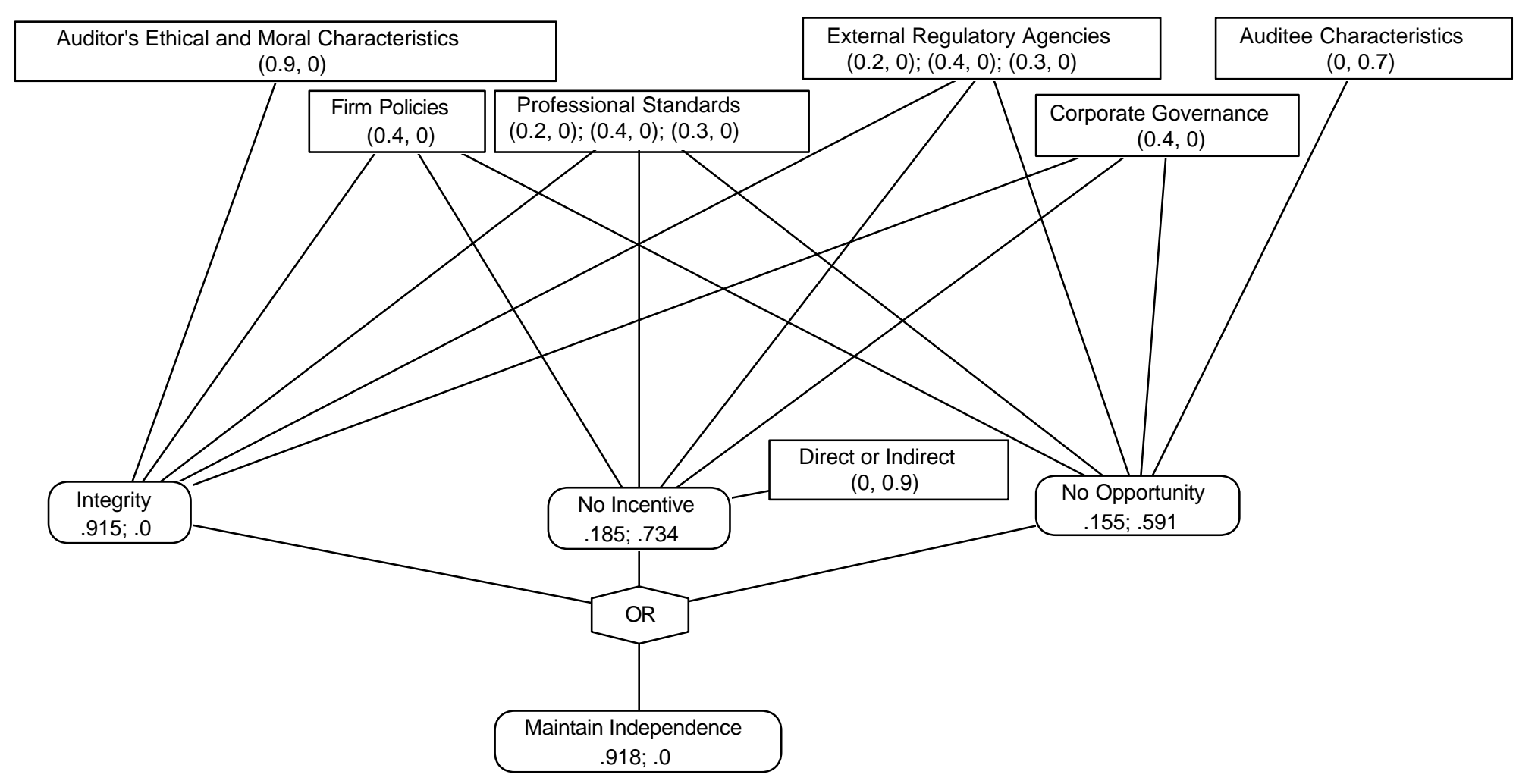

* In the above independence risk model, a rectangular box with rounded corners represents a variable node and a rectangular box represents an independence factor node pertaining to the variable(s) to which it is linked. The first number in the variable node represents the level of belief ("belief value") that the variable is true and the second number represents the level of belief that the variable is not true. The independence factor nodes-Professional Policies, and External Regulatory Agencies - contain three sets of numbers each. In each case, these sets of numbers from left to right, respectively, pertain to the variables 'Integrity', 'No Incentive', and 'No Opportunity'. The first number in parentheses represents the belief that the corresponding variable is true and the second number represents the belief that the corresponding variable is not true. 
Figure 2

The Impact of Auditor Integrity on Independence Risk

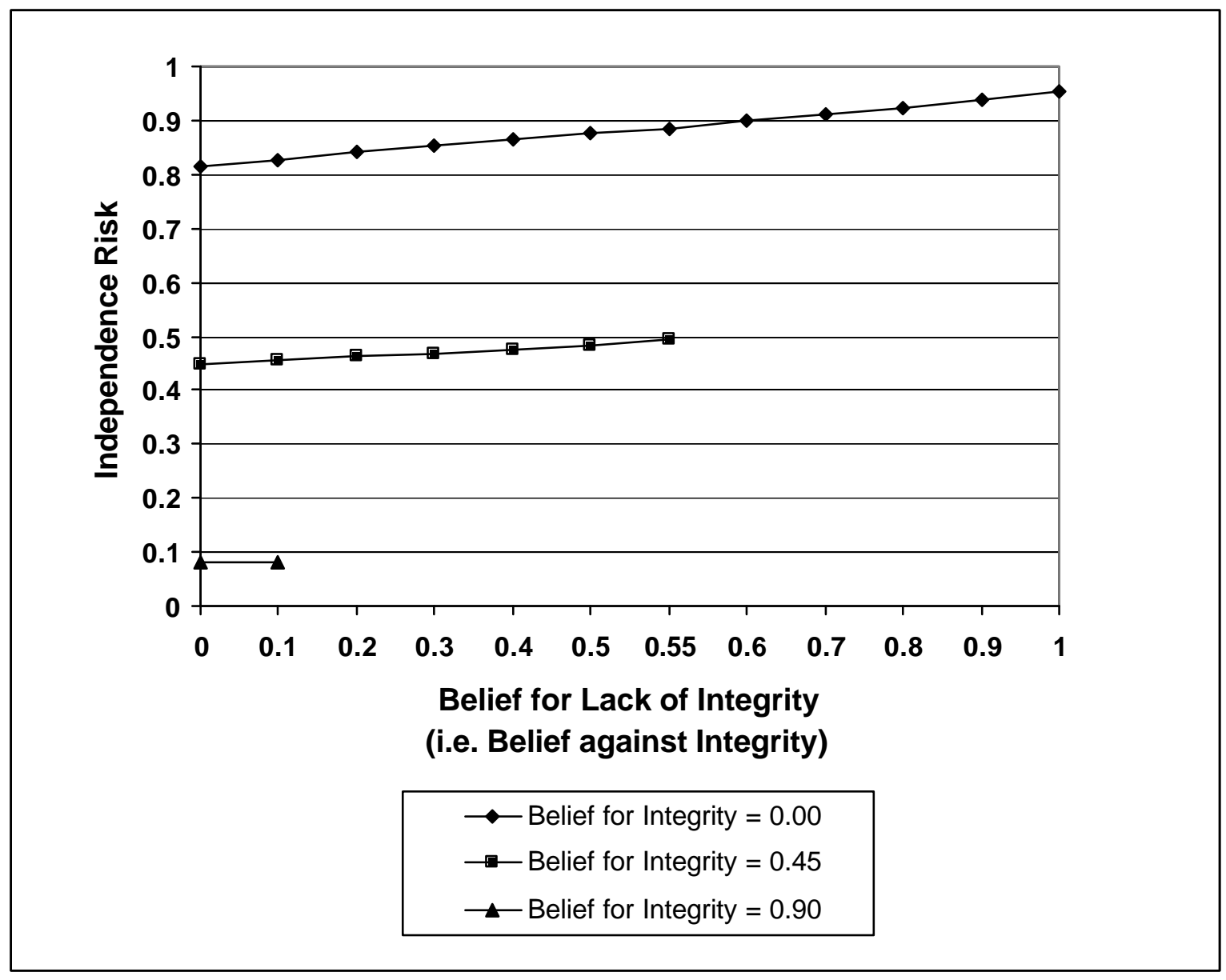


Figure 3

The Effect of Professional Standards on Independence Risk*

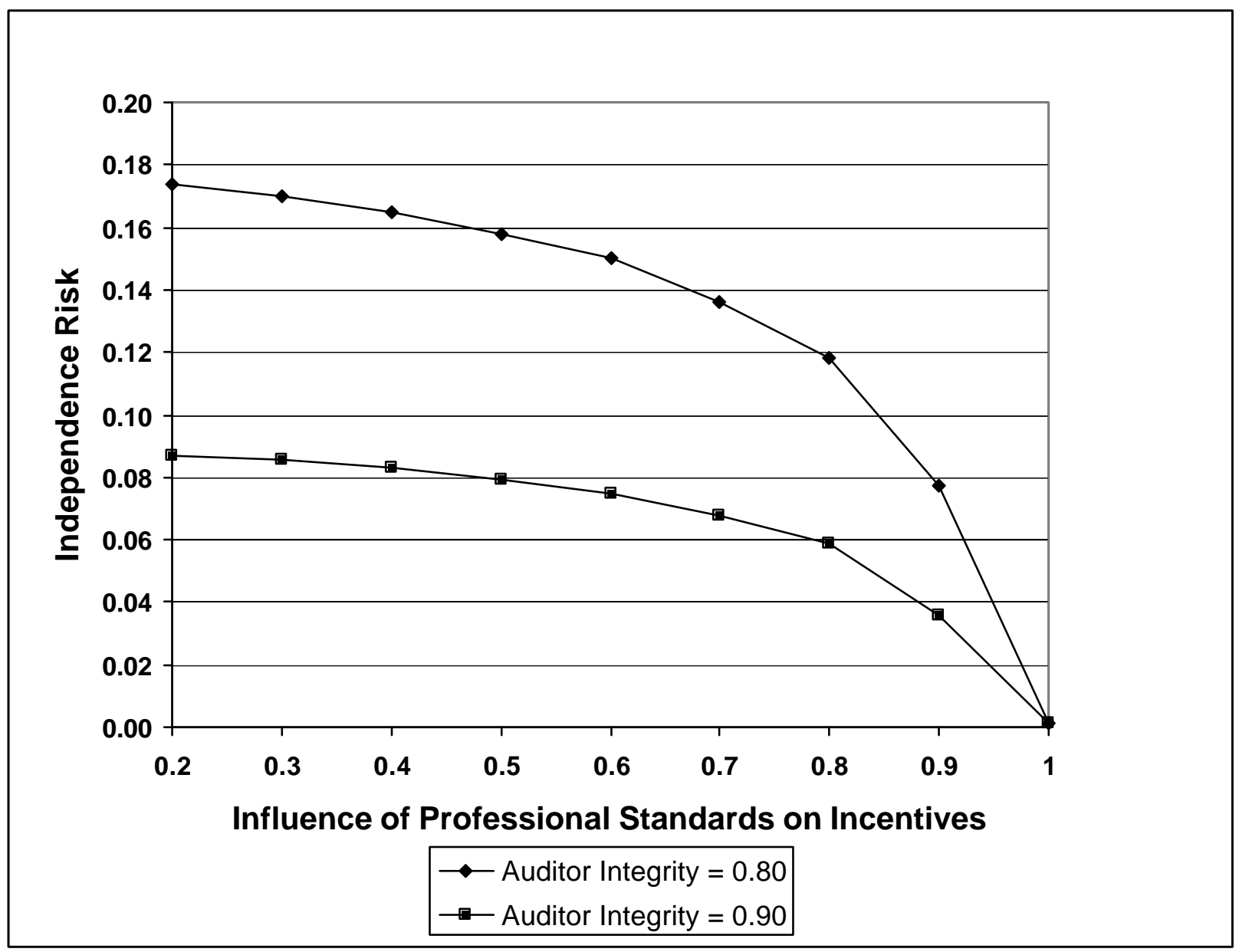

* While the belief from Professional Standards for No Incentive plotted along the X-axis varies from 0.2 to 1.0, the belief from Professional Standards for Integrity and No Opportunity increments from 0.10 to 0.50 and from 0.15 to 0.75 , respectively. 
Figure 4

The Impact of Auditee Characteristics and Direct/Indirect Incentives on Independence Risk

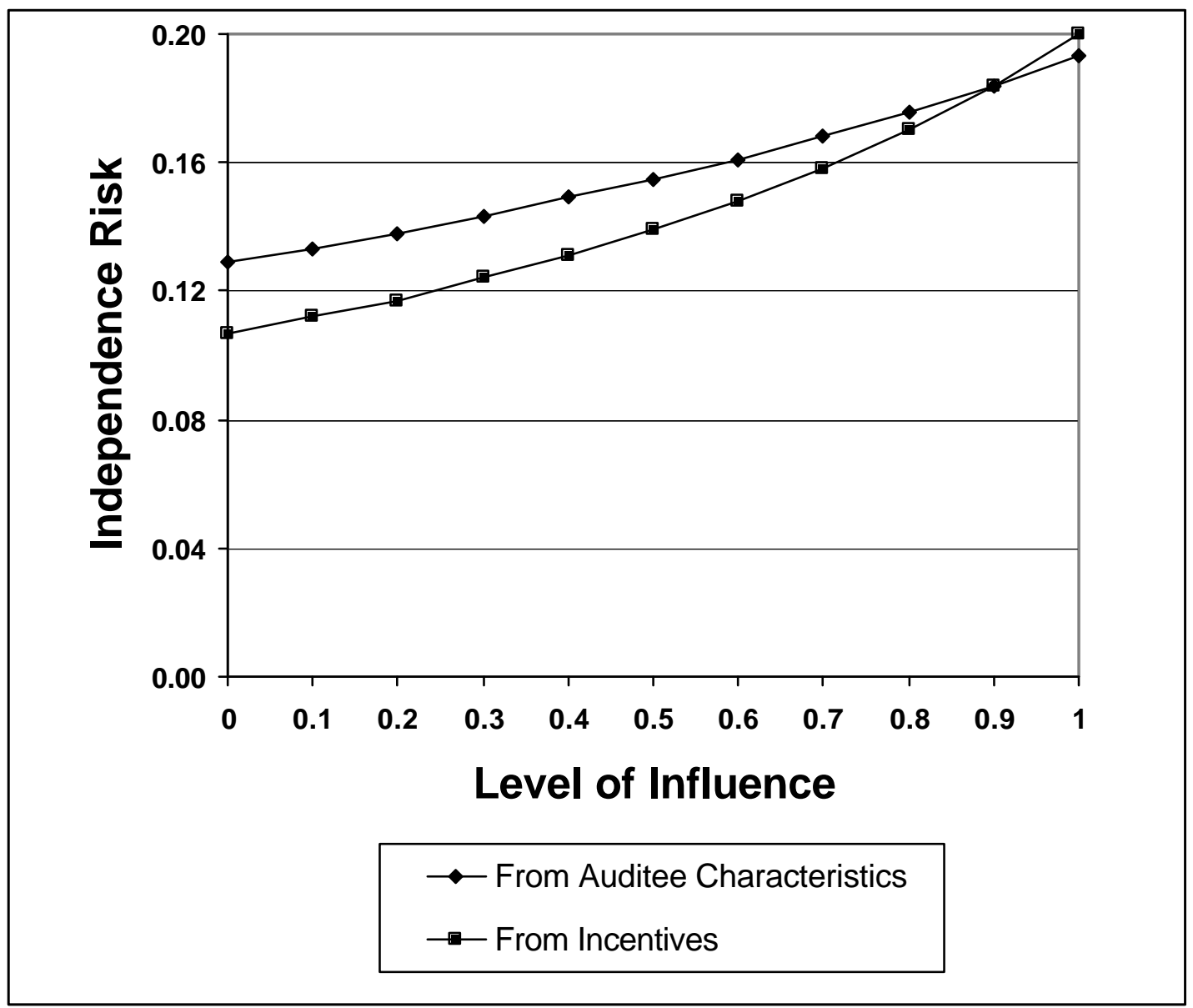

